\title{
CAÇADORES CANIBAIS E CABEÇAS PERIGOSAS: A CENSURA E O MERCADO DE LITERATURA PORNOGRÁFICA NO REGIME DE 64
}

\author{
Rodolfo Rorato Londero ${ }^{1}$
}

Resumo: O objetivo deste artigo é abordar a censura de romances pornográficos durante a última ditadura civil-militar brasileira, considerando 0 ponto de vista do mercado editorial. As obras de Adelaide Carraro e Cassandra Rios serão tomadas como exemplo, devido tanto ao apelo popular quanto à perseguição da censura que ambas experimentaram. $O$ artigo aborda a censura enquanto produto social, procurando refletir sobre o papel da censura nas estratégias do mercado editorial, na formação de circuitos populares e paralelos de leitura e na constituição do público leitor.

Palavras-chave: censura; pornografia; mercado editorial.

Abstract: The purpose of this article is to address the censorship of pornographic novels during the last Brazilian civil-military dictatorship, considering the perspective of the publishing market. The works of Adelaide Carraro and Cassandra Rios will be taken as an example, due to both the popular appeal as the persecution of censorship that both experienced. The article discusses censorship as a social product, seeking to reflect on the role of censorship in the strategies of publishing market, in the formation of popular circuits and reading parallels and in the constitution of the reading public.

Keywords: censorship; pornography; publishing market.

A historiografia recente procura desfazer a inevitável narrativa de resistência que se criou em torno da última ditadura civil-militar brasileira. Um bom exemplo é o segundo volume de $A$ construção social dos regimes autoritários (2010), organizado por Denise Rollemberg e Samantha Quadrat, dedicado aos regimes latino-americanos. $\mathrm{Na}$ apresentação desta obra, as autoras propõem uma narrativa da ditadura brasileira que, ao invés de baseada somente em "instituições e práticas coercitivas e manipulatórias", seja também

\footnotetext{
${ }^{1}$ Professor Doutor no Curso de Comunicação Social da Universidade Estadual de Londrina - UEL. Email: rodolfolondero@bol.com.br
} 
compreendida como "produto social" (Rollemberg; Quadrat, 2010: 11). Portanto, ao invés de entender a censura de romances pornográficos somente como prática repressiva, deve-se considerá-la também como produto da tradição censória brasileira ${ }^{2}$, como resposta ao mercado editorial, como reação do público, etc. Enfocando o público e o mercado editorial, este artigo pretende abordar a censura de diversões públicas a partir de outro ângulo, afastada de seu órgão executor, a DCDP (Divisão de Censura de Diversões Públicas), mas próxima daqueles que a experimentavam, seja como cerceamento (no caso dos leitores e editores), seja como dever cívico (no caso dos censores amadores $^{3}$ ). Toma-se como exemplo as obras de Adelaide Carraro e Cassandra Rios, pois se trata das obras mais vendidas (ambas as escritoras somam mais de 4 milhões de exemplares vendidos) e mais censuradas (13 e 17 livros censurados, respectivamente ${ }^{4}$ ) no período analisado.

Por público deve-se compreender aqui não apenas os leitores, mas também todos aqueles que contribuem para a publicação e a distribuição das obras (editores, impressores, livreiros, etc.). Apesar de não constituírem o público, os editores e livreiros tornam a obra disponível e acessível para o público, sendo importante analisá-los em conjunto. Na verdade, sem se apoiar em seus relatos e em reportagens sobre o mercado editorial, a reconstrução do público dos romances de Cassandra e Adelaide seria impossível. Também não se pode ignorar que, enquanto mediadores entre a obra e o público, esses atores sociais eram extremamente visados pela censura, tanta a implementada oficialmente pelo Estado quanto a praticada amadoramente por civis que se consideravam defensores da moral e dos bons costumes.

Segundo Escarpit, sem o editor, "a obra concebida elevada aos limites da criação não anuiria à existência" (Escarpit, 1969: 99). Em outras palavras, é o editor quem transforma a obra em livro, em objeto de consumo. Para Escarpit

\footnotetext{
${ }^{2}$ Em sua dissertação Salvando a pátria da pornografia e da subversão (2006), Douglas Marcelino afirma que "a censura de diversões públicas [...] estava ancorada em uma forte tradição de censura de costumes que, além de anteceder em muito aos anos de ditadura militar, se enraizava em convicções profundas sobre a necessidade de se resguardar certos padrões morais tidos como típicos da sociedade brasileira" (Marcelino, 2006: 18).

${ }^{3}$ Este artigo não pretende abordar o problema da censura amadora, remetendo o leitor ao artigo esclarecedor de Carlos Fico, "Prezada Censura" (2002).

${ }^{4}$ Dados baseados em levantamento realizado por Reimão (2011, p. 127), além de consulta própria em jornais e revistas. É provável que esses números sejam bem maiores, apesar da dificuldade de verificá-los livro por livro: uma reportagem do jornal Folha de S. Paulo (20 de junho de 1977) contabilizava 28 romances apreendidos de Cassandra e onze de Adelaide.
}

|74| Revista Eletrônica Literatura e Autoritarismo, o 25 - janeiro a junho de 2015 - ISSN 1679-849X http://cascavel.ufsm.br/revistas/ojs-2.2.2/index.php/LA/index 
(1969: 106-107), as funções dos editores resumem-se em três verbos: escolher, fabricar e distribuir. Primeiro os editores selecionam quais obras serão publicadas, depois determinam como elas serão impressas e, por fim, buscam os canais de distribuição (anúncios, livrarias, bancas de jornal, etc.).

Sobre a primeira função (escolher), o editor "tenta agir sobre os autores em nome do público e sobre o público em nome dos autores, numa palavra, conseguir um público e autores regulados uns pelos outros" (Escarpit, 1969: 108). Nesta tarefa de regulador, o editor acaba criando hábitos de leitura: "Estes hábitos podem tomar a forma de modas, de esnobismos e até mesmo de predileções passageiras pela personalidade de um autor" (Escarpit, 1969: 109). Este é o caso dos editores de Cassandra e Adelaide, devido tanto à promoção do gênero pornográfico quanto à celebração da imagem de maldita e proibida conferida às autoras. Sempre combatendo esta imagem, Cassandra não ignorava, contudo, a oportunidade de mercado representada pelo filão pornográfico, pois assim se manifestava uma personagem apresentada em seu livro autobiográfico:

Não quero ser indelicado, mas não sou apenas um comerciante de livros, sou um editor que procura conhecer mais profundamente a obra que edita, analisando-a e classificando-a, às vezes cometem-se alguns erros por fins comerciais, mas isso não quer dizer que não façamos distinções. Às vezes fazemos promoções de certos gêneros em obras que vendem para que se tornem mais difundidas, aí as falsas ideias em relação a determinados autores injustamente enquadrados na faixa dos proibidos (Rios, 1977: 23).

Não é por acaso que Cassandra fez sua defesa por meio das palavras de um editor, pois ela sabia que este também contribuía e lucrava com a imagem de maldita que tanto a aborrecia. No caso dos "erros para fins comerciais" cometidos pelos editores, ou seja, dos elementos que forçavam uma leitura pornográfica das obras, o mais evidente eram as capas, também criticadas por Cassandra: "Poderia gastar páginas para defesa dos meus trabalhos [...] e alguns outros cujas capas abominei, mas isso é assunto da Editora e raramente o autor escolhe e opina" (Rios, 1977: 10-11). A escolha da capa, entre outros elementos, se refere à segunda função do editor (fabricar): segundo Escarpit, se o desenho da capa é bem escolhido, ele deve "traduzir 
graficamente a análise estético-psicológica à qual o editor se entregou para fazer a seleção" (Escarpit, 1969: 113). Ou seja, a capa deve indicar o gênero (estética) e o público (psicologia) visado pelo editor, determinando assim a leitura e os leitores pretendidos para a obra. Os leitores não "encontrarão" o drama dos menores abandonados em Submundo da sociedade, ainda que seja este o enredo da primeira metade do romance de Adelaide, pois a capa da segunda edição apresenta uma mulher nua, seios à mostra.

Não se procura aqui eximir as obras das autoras de conteúdo pornográfico, mas compreender a "onda de erotismo", denunciada pelo Estado e pelos setores conservadores do regime civil-militar, como um fenômeno editorial. Um quadro ilustrativo deste fenômeno foi apresentado pela reportagem "É a explosão erótica nas livrarias", publicada pela revista Veja em 20 de novembro de 1968. A reportagem listava vários livros pornográficos editados pelo mercado brasileiro, como era o caso do clássico Minha vida, meus amores (1888), de Henry Spencer Ashbee, que esgotou 10 mil exemplares em apenas 25 dias (Explosão, 1968: 60). Na carta do editor publicada na edição seguinte, Victor Civita se mostrava entusiasmado com a repercussão da reportagem:

\begin{abstract}
Exemplar de VEJA na mão, o homem de meia-idade entrou apressadamente na Livraria Brasilense, no centro de São Paulo. "O senhor me vê um exemplar de 'Minha vida, Meus amores' e um 'Kama Sutra'", pediu ao vendedor. A procura de livros eróticos começou na tarde de segunda-feira, dia 18, pouco depois de ter chegado às bancas o número 11 de VEJA, com uma reportagem chamada "É a explosão erótica nas livrarias". Às 10 horas da manhã seguinte, terça-feira, a Brasiliense havia esgotado todo o seu estoque de literatura erótica ("Tapete de Carne", "Filosofia na Alcova", além dos citados) e seus funcionários telefonavam ininterruptamente aos distribuidores pedindo mais livros para atender à procura continuada (Civita, 1968: 13).
\end{abstract}

As palavras otimistas de um romancista estreante finalizavam a reportagem, apontando para um futuro promissor do mercado de literatura pornográfica: "Na atual explosão erótica brasileira, cedo haverá outros Josés Cláudios por todo o País, tentando 'retratar a vida em todos os seus detalhes, sem qualquer restrição às liberdades artísticas"” (Explosão, 1968: 63). Mal se imaginava que, pouco mais de um ano após a publicação da reportagem, 
surgiria o principal instrumento legal do regime contra a pornografia, o Decreto-

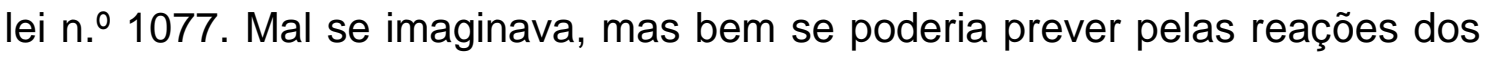
leitores que comentaram a reportagem na seção "Cartas", da edição de 11 de dezembro de 1968. Das três cartas publicadas, duas criticavam a matéria, enquanto uma elogiava. Se a reportagem de Veja serviu de guia literário para o homem de meia-idade citado por Civita, ela também se mostrou como um catálogo de leituras impróprias para adolescentes, segundo um dos missivistas:

Sr. Diretor: VEJA, em sua reportagem sobre erotismo na literatura, pretende fazer uma matéria educativa. Em vez disso, a matéria sugere aos mais desavisados a leitura desses livros, dando inclusive uma relação dos livros eróticos existentes no Brasil. Coisas assim não deveriam ser tratadas numa revista manuseada por adolescentes. Péssima lição para nossa juventude brasileira! (Cartas, 1968: 3).

Mais um exemplo de apoio popular que, aliado à tradição censória

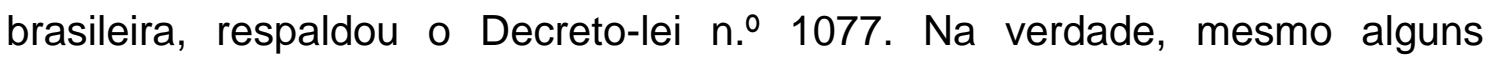
editores de literatura pornográfica, como Eli Behar, da Editora Hemus, apoiavam a censura prévia estabelecida pelo decreto, pois acreditavam que ela "pode evitar os prejuízos causados por edições de livros já apreendidos" (Sete, 1970: 20). Como já se sabe, isto jamais aconteceu, porque nem os autores nem os editores sabiam quais eram os critérios da censura. O que a declaração de Behar apresenta de novo é a perseguição rotineira de livros pornográficos antes da publicação do decreto-lei. A partir de mandados de Juizados de Menores, as apreensões aconteciam principalmente em feiras do livro, como mostrou o jornal Diário Carioca, em notícia publicada em 23 de maio de 1964: "Só na Feira do Livro, na Praça Floriano, foram apreendidos, esta semana, mais de 40 volumes dessas obras" (Livros, 1964: s. p.), sendo citados cinco títulos de Cassandra (Copacabana Posto 6, Georgette, Eudemônia, O bruxo espanhol e Carne em delírio). Sobre a mesma feira, o jornal Correio da Manhã (31 de maio de 1964) informou que os livros foram acusados de "impróprios para o consumo" e subversivos (Feirantes, 1964: 9). Mesmo antes do golpe civil-militar, o jornal Última Hora (4 de abril de 1962) relatava que "os livros de Rabelais, Rimon, Cassandra Rios e 'A carne', de Júlio Ribeiro, estão sendo apreendidos aos montes pela polícia" (São Paulo, 
1962: 4). Diante desse quadro caótico, os editores esperavam da censura prévia uma solução que estabilizasse o mercado de livros, que tornasse a produção de livros uma atividade menos arriscada.

Após o decreto, mesmo a entidade que deveria proteger os editores se mostrou intransigente quando se tratava de literatura pornográfica, principalmente porque, segundo ex-presidente da Câmara Brasileira do Livro, Mário Fittipaldi, a entidade zelava por "dotar o país dos livros necessários ao seu desenvolvimento" (Fittipaldi, 1984: 73). Comentando o decreto-lei logo após sua publicação, em um seminário de jornalismo realizado na Universidade de São Paulo em 1970, Fittipaldi o apoiou justificando que

a faculdade criadora, por exemplo, está sendo sacrificada em certos setores pela produção não somente de livros, mas principalmente de revistas e folhetos verdadeiramente degeneradores da moral e dos costumes. Alguns editores não se limitam a estimular a produção nacional do mais desabrido imoralismo e traduzem livros medíocres da subliteratura mundial, cuja nota predominante está no sexualismo (Fittipaldi, 1984: 77).

$\mathrm{Na}$ verdade, após o decreto, os editores de livros pornográficos tinham duas opções: ou submeter o livro à avaliação prévia ou publicá-lo correndo o risco de apreensão e destruição da tiragem (Gonçalo Junior, 2010: 216). Como os critérios da censura se mostravam enigmáticos, tanto a primeira quanto a segunda opção eram arriscadas. Caso se submetesse o livro à censura e ela 0 vetasse, o possível lucro era perdido. Caso não o submetesse, mas a censura o apreendesse, o capital já investido era perdido. Alguns editores optaram pela segunda opção, pois, como afirma Marcelino, "aqueles eram tempos em que equipes de busca saíam às ruas revistando jornaleiros e livrarias à procura de publicações tidas como pornográficas", calculando 226641 exemplares apreendidos apenas no ano de 1978 (Marcelino, 2006: 154-155). Se muitos exemplares foram apreendidos, então é porque alguns editores não submeteram os títulos à censura prévia.

Deve-se acrescentar ainda outra dificuldade para os editores que seguiam por esse caminho: a impressão da tiragem, pois as gráficas, temendo má reputação junto ao governo, exigiam a liberação da censura para rodar material pornográfico (Gonçalo Junior, 2010: 219). Os editores que optavam 
por não submeter os livros à censura deveriam encontrar ou gráficas clandestinas ou gráficas menos exigentes quanto aos trâmites da censura. Isto também explica porque um procedimento de praxe no meio editorial era raramente adotado nessas ocasiões: a inserção do nome e do endereço da gráfica na última página do livro. Os livros de Cassandra e Adelaide publicados na primeira metade da década de 1970, principalmente pelas editoras Global, Mundo Musical e L. Oren, não apresentam nenhuma informação sobre as gráficas que os imprimiram.

Caso se lembre que, no Brasil de antes e mesmo no de hoje, o luxo é o livro, pois é um objeto caro num país de analfabetos ou semianalfabetos (Santiago, 1982: 26), então melhor se visualiza a dimensão do risco da empreitada editorial. Mesmo os best-sellers de Cassandra e Adelaide que, devido à grande tiragem e à sensibilidade popular, poderiam parecer acessíveis a todas as classes, não os eram: "Com certeza, a procura desses livros, por parte do proletariado, é insignificante visto que o preço de cada volume está em torno de $\operatorname{Cr} \$ 70,00$, inacessível ao seu poder de compra" (Caldas, 1978: 7). Verificado este preço em abril de 1978, o exemplar representava 6,3\% do salário mínimo da época $(\operatorname{Cr} \$ 1106,40)$. Neste sentido, os livros de Adelaide também eram luxo, como a própria autora reconhecia ao responder que a classe social que lê seus livros é aquela "que tem problemas, tristeza na vida, menos o operário que não compra livros. Ele não tem dinheiro para isso" (Carraro apud Caldas, 1978: 7). No caso do regime de 64, além do risco de fracasso de vendas inerente à condição de luxo do livro, somava-se também o risco de censura: Luiz Alves Junior, editor da Global, disse ao jornal Folha de $S$. Paulo que perdeu mais de 500 mil cruzeiros devido às proibições e quase pediu concordata (Amâncio, 1977: 19).

Para retornar às funções editoriais, há também a distribuição, quando o editor busca "encontrar, e atingir na realidade, o público teórico que ele supôs e imaginou desde o começo" (Escarpit, 1969: 114). Neste ponto, segundo Escarpit, há dois sistemas de distribuição: o circuito letrado, centrado em livrarias tradicionais, e os circuitos populares, disseminados em bancas de jornal, lojas de conveniência, drogarias, feiras do livro, enfim, em estabelecimentos que "se dedicam de forma acessória à venda de livros" 
(Escarpit, 1969: 140-141). Eram nos circuitos populares que se encontravam mais facilmente os livros de Cassandra e Adelaide:

Em São Paulo, por exemplo, nas livrarias da Avenida São João, onde se misturam discos, livros, fitas cassetes, etc., nas imediações das estações ferroviárias e rodoviárias, além das bancas de jornal. Por outro lado, nas livrarias especializadas em livros científicos e literatura dos grandes escritores, dificilmente encontram-se obras de autores que produzem a subliteratura (Caldas, 1978: 6).

Os livros das autoras vendiam-se, portanto, em grandes vias de acesso bastante movimentadas (as "livrarias-discotecas" da Avenida São João), ao invés de em lugares afastados, como as livrarias dos "bairros classe média periféricos ao centro" (Caldas, 1978: 7). Uma das editoras que mais publicaram livros de Cassandra e Adelaide, a Global, surgiu através dos circuitos populares, a partir de uma distribuidora que a antecedeu: segundo o editor Luiz Alves Junior,

a farmácia era um ponto ideal para se vender, aproveitando um decreto-lei do ministro Jarbas Passarinho, da Educação, dizendo que as farmácias poderiam vender livros. (...) Como tinha muito mais farmácias do que livrarias, a ideia foi boa e nós montamos a Farma Livros em 1971. E essa Farma Livros pegava os livros de todas as editoras para distribuir nesses pontos de farmácias, depois foi para supermercados, postos de gasolina, salões de cabeleireiro, uma coisa enorme. (...) Em 1973 a gente achou por bem montar uma editora já com o feeling daquilo que a gente estava vendendo melhor. (...) Os livros de Cassandra e Adelaide vendiam muito. Vendiam-se muitos livros de faroeste, muitos romances de bolso (policial sexy), vendia-se muito também essa área sexy (Alves Junior, 2011).

Não por acaso, o primeiro livro publicado pela Global foi justamente um romance de Adelaide, Submundo da sociedade. Em entrevista para esta pesquisa, Luiz Alves contou como isto aconteceu, revelando não apenas o "feeling" da editora, mas também o faro comercial da autora:

Um dia me aparece uma senhora lá na Farma Livros, com um "macacão da Texaco", toda de branco. Pensei que fosse uma frentista. Simpática.

- Você sabe com quem está falando? 
- Não tenho nem ideia.

- Você está falando com Adelaide Carraro.

- Que bom! Que ótimo! Você está chegando num momento bom aqui nesta casa, porque nós já vendemos muito seus livros.

- É por vocês estarem vendendo muito meus livros que eu quero editar um livro com vocês.

- Mas nós não temos nem editora, nós estamos formando uma editora agora, é só distribuidora de livros, a Farma Livros.

Então antecipamos, mais ou menos para outubro de 73 , e publicamos o livro perto do final de 73, o livro Submundo da sociedade, da Adelaide (Alves Junior, 2011).

Ao visitar a então distribuidora Farma Livros, valendo-se de suas credenciais de escritora de best-sellers, Adelaide sabia que seu público pouco frequentava as livrarias, sendo mais fácil "capturá-lo" através dos circuitos populares. Sobre esses circuitos, Escarpit afirma que "a associação do comércio do livro com outros comércios (papelaria, jornais, tabaco, alimentação) coloca os livros nos trajetos da vida cotidiana. Já não é preciso ter o incômodo de entrar numa livraria" (Escarpit, 1969, p. 142). Também é assim que Caldas explica a comercialização dos livros de Cassandra e Adelaide na Avenida São João:

O grande centro de São Paulo é mais ou menos uma espécie de "terra de ninguém". Apesar de ser a área de lazer dos baixos estratos da população, é também ponto de passagem de profissionais das mais diversas qualificações, tornando esse público indiferenciado. Anônimo. E por isso, principalmente, que as livrarias-discotecas do centro dão grande destaque em suas vitrines às obras de Adelaide Carraro, Cassandra Rios e outros escritores ligados à subliteratura. Isto porque, apesar da heterogeneidade do público, predomina o leitor não comprometido com a literatura dos grandes escritores (Caldas, 1978: 7).

Expunham-se os livros nos estabelecimentos do grande centro de São Paulo porque por eles transitavam um grande número de pessoas, portanto, um grande número de clientes potenciais. Eram pessoas que, como hoje, pouco tempo dispunham para entrar numa livraria. Elas não queriam procurar o livro: o livro deveria encontrá-las. Isto não significa, entretanto, que a "literatura dos grandes escritores" ou os livros políticos e científicos jamais cruzavam os seus caminhos. As já mencionadas feiras do livro, ponto marcado da censura, 
apresentavam uma grande diversidade de livros e se localizavam quase sempre em praças do centro urbano, como a da Cinelândia, no Rio de Janeiro. Sobre uma dessas feiras, apesar de afastada do centro carioca (Praça Saens Peña, no bairro Tijuca), o jornal Diário de Notícias mostrava a variedade de títulos comercializados, informando em manchete que "Sexo lidera vendas na Feira do Livro" (8 de junho de 1975):

Outros livros procurados são os específicos em economia, tais como: Leo Huberman (A História da Riqueza do Homem), Marx (O Capital); em sociologia, livros de bolso (por serem mais baratos), além do erótico, dos autores Guy Giscard e Cassandra Rios. A literatura infantil é vendida em coleções, que são escolhidas pelas próprias crianças. O dicionário de Aurélio Buarque de Holanda - Novo Aurélio - já está esgotado (Sexo, 1975: s. p.).

Bibliografia marxista, literatura erótica e crianças inofensivas por todo 0 lado: as feiras do livro certamente figuravam como um pandemônio na cabeça de qualquer padre conservador ou militar paranoico. Evidente nessas feiras, a mistura de públicos problematiza a separação que Marcelino defende entre "uma parcela mais intelectualizada da juventude", que adotava novas posturas comportamentais e rejeitava a ordem política vigente, e aqueles que consumiam "erotismo sem preocupações de natureza ideológica" (Marcelino, 2006: 20). Ainda que esta divisão remeta a dois modos formalmente diferentes de censura, a moral e a política, não se pode daí deduzir públicos incomunicáveis, tais como jovens idealistas castos e consumidores de pornografia alienados. Salvyano de Paiva, numa crônica para o jornal Correio da Manhã (8 de novembro de 1968), descrevia os hábitos de leitura do público feminino estudante e universitário:

Ela lê Hotel, Hospital, Marcuse, McLuhan, Servan-Schreiber, Guevara, e quando chega a J. D. Salinger, por exemplo, é para saber se Fanny desmaiou por estar grávida ou por ter inibições morais e dúvidas religiosas. (...)

Dos 15 aos 24 anos ela se distingue da mamãe - pela ênfase no assunto sexo. Por isso, o êxito espantoso de Sexus, de Henry Miller, e das novas coleções eróticas que os editores, ávidos, estão lançando, inclusive obras importantes de Aretino, Sade, Masoch, de cambulhada com as Cassandra Rios de todas as latitudes (Paiva, 1968: 2). 
A mesma jovem que protestava, que lia Marcuse e Guevara, era também a jovem que queria compreender a sexualidade: sobre as obras pornográficas vendidas numa feira do livro de Porto Alegre, a então Secretária da Educação disse que os maiores compradores desses "livrinhos semvergonhas" eram "mocinhas adolescentes", como afirmou para a revista Veja em reportagem já comentada ("É a explosão erótica nas livrarias"). A reportagem explicava isto afirmando que, devido à "ausência de uma educação sexual", os livros se tornavam "uma fonte de esclarecimento sobre os 'fatos da vida"' (Explosão, 1968: 61). O escritor Marcelo Rubens Paiva comenta o sucesso (e a censura) de Cassandra do mesmo modo: "Tratava-se de uma mulher escrevendo sobre tesão de mulher, numa sociedade cuja predominância religiosa afirmava que a mulher apenas se deitava com um

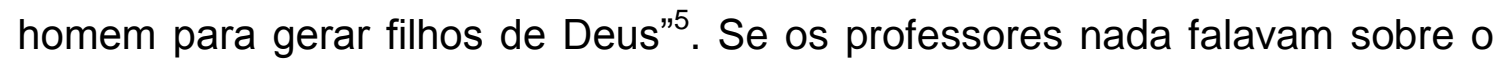
assunto e os padres direcionavam a sua abordagem (o sexo como procriação, e não como prazer), sobrava aos livros pornográficos a tarefa de ensinar sobre o sexo, mesmo não sendo esta sua função.

Ainda sobre os circuitos de distribuição, talvez a expressão mais adequada para o caso que se estuda é circuitos paralelos ou circuitos clandestinos. Neste sentido, é interessante destacar a ingenuidade ou o cinismo de um técnico de censura ao comentar que "há muitos anos vem sendo vendidos clandestinamente [os livros de Cassandra Rios], onde concluímos que até os próprios editores não ousavam lançá-los abertamente ao público devido ao seu conteúdo altamente atentatório à moral e aos bons costumes" . A censura preferia ignorar que ela mesma acabou criando um mercado editorial clandestino. Sobre as editoras que participavam deste mercado, Gonçalo afirma que

a maioria atuava de forma clandestina na região central de São Paulo, na Boca do Lixo, mais conhecida pela produção de filmes de pornochanchada. Dentre elas, destacavam-se as editores Ebex Brasil, Edições Sucessos Literários, L. Oren, Royal e Global GD, que se tornaria uma conceituada editora de livros sobre a ditadura militar (Gonçalo Junior, 2010: 388).

\footnotetext{
${ }^{5}$ Disponível em <http://www1.folha.uol.com.br/folha/ilustrada/ult90u22181.shtml>. Acesso em 28 ago. 2012.

${ }^{6}$ Parecer n. ${ }^{\circ}$ 1755/75, de Ascension Palacios Chanques, 30 out. 1975, Arquivo Nacional.
} 
Localizada próxima da Estação da Luz, mais precisamente na Rua do Triunfo, a Boca do Lixo atraía as editoras principalmente por se encontrar algumas quadras da Avenida São João, principal escoadouro de livros pornográficos. Na verdade, no início da década de 1960, tanto o endereço da editora própria que Cassandra abriu após sua condenação em 1962 (Gonçalo Junior, 2010: 198) quanto o endereço da editora dos primeiros livros de Adelaide (Livraria Exposição do Livro ${ }^{7}$ ) localizavam-se na Avenida São João. Entretanto, das editoras citadas por Gonçalo, apenas a L. Oren e a Global publicavam livros de Cassandra e Adelaide, e apenas a primeira se encontrava próxima da Boca do Lixo, na Av. Ipiranga. Este endereço constava em livros da editora publicados durante a primeira metade da década de 1970. A partir daí, a editora se mudou para endereços mais afastados, como na Vila Carolina, no Bairro do Limão e na Água Branca, todos na zona oeste de São Paulo. Duas hipóteses podem explicar esta mudança constante de endereço: problemas financeiros (o aluguel dos bairros periféricos é mais barato) e/ou perseguição da censura. Por outro lado, ao longo dos anos 1970, os livros da editora Global apresentavam o mesmo endereço, localizado em Vila Mariana (zona sul). Do mesmo modo, nos livros da editora Mundo Musical, não citada por Gonçalo, mas responsável por vários livros de Cassandra, constavam o mesmo endereço, localizado em Pirituba (zona noroeste). Comparada às mudanças da editora L. Oren, a "estabilidade" dessas editoras também levantava suspeita sobre a autenticidade de seus endereços, sendo talvez mais um artifício para enganar a censura.

Pouco se sabe sobre como essas editoras clandestinas distribuíam seus livros, ou seja, como se desenvolviam os circuitos paralelos. Em entrevista para esta pesquisa, o editor da Global, Luiz Alves, afirmou que "era uma venda mais caseira, onde a pessoa interessada era da casa, era da livraria, já era conhecida. Até esse cuidado a gente tinha, porque se era um cara estranho, podia ser um agente [da polícia] disfarçado" (Alves Junior, 2011). Além de restringir o círculo de vendas aos laços de confiança, os editores também se

\footnotetext{
${ }^{7}$ Ao final dos anos 1960, ainda no mesmo endereço, a Livraria Exposição do Livro transformou-se em Editora Hemus e começou a reeditar alguns livros de Cassandra Rios, como A serpente e a flor (1965) e Tessa, a gata (1965). Contudo, no início dos anos 1970, a editora mudou-se para o bairro República, pouco mais de dois quilômetros distantes da Avenida São João.
}

|84| Revista Eletrônica Literatura e Autoritarismo, oo 25 - janeiro a junho de 2015 - ISSN 1679-849X http://cascavel.ufsm.br/revistas/ojs-2.2.2/index.php/LA/index 
escondiam por algum tempo após a publicação de livros que certamente chamariam a atenção dos órgãos de censura. O editor da Global fez isto em 1977, após distribuir nas bancas de jornal os três primeiros volumes da Coleção Bases, conhecida por seus livros comunistas: Dez dias que abalaram o mundo, de John Reed; Poética, de Maiakovsky; e A origem do capital, de Karl Marx (Alves Junior, 2011).

Quando se tratava de distribuir livros de editoras de outros estados, como as memórias do general Olympio Mourão Filho ( $A$ verdade de um revolucionário), publicadas pela editora gaúcha L\&PM em 1978 e depois censuradas, Luiz Alves descreveu o seguinte esquema:

O livro vinha para São Paulo de avião com outro título. Ali mesmo já estavam emitidas as notas fiscais com o outro título, não o verdadeiro. Ali do próprio aeroporto, quando a gente recebia a carga, colocava dentro de duas Kombis. (...) Não vinha quase nenhum livro para a editora, porque a gente não queria correr o risco. Então a gente já tinha as vendas para fora de São Paulo e para a grande São Paulo. As vendas para São Paulo ficavam nas Kombis e a gente distribuía escondida (Alves Junior, 2011).

Além das notas frias que ocultavam o verdadeiro título dos exemplares, as distribuidoras os vendiam antecipadamente aos livreiros de confiança, visando não produzirem um estoque comprometedor.

Uma personagem que certamente atuava nesses circuitos paralelos era o atravessador. Uma reportagem do Jornal da República revelou como atuavam esses atravessadores, ainda que em situações específicas, como

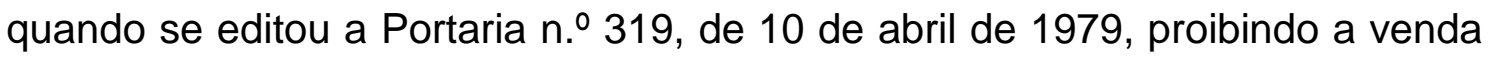
de livros pornográficos em bancas de jornal. Segundo a reportagem, a Global, liderando outras editoras, entrou na Justiça contra a portaria. Contudo, sem aguardar a decisão judicial, algumas editoras "preferem arriscar-se na mão de pequenos negociantes que operam numa espécie de circuito paralelo, entregando livros para as bancas do centro e das rodoviárias, mesmo sob o risco de perder tudo" (Markun, 1979). É possível imaginar que esses "pequenos negociantes" já atuavam antes da portaria, principalmente repassando livros proibidos, pois, segundo Cassandra, algumas gráficas continuavam imprimindo clandestinamente seus livros mesmo após os vetos da censura: 
Quantas coisas acontecendo enquanto este livro está sendo escrito. Descobriram edições clandestinas dos livros de Cassandra numa gráfica. Urgentemente necessário tomar providências. Ligou para a Editora no Rio de Janeiro, afinal não recebia direitos autorais desde a proibição do primeiro livro. Mandaram-na comunicar-se com a filial da Editora em São Paulo mesmo, para averiguações. Ficaram de dar notícias a respeito no dia seguinte, iriam tomar as devidas providências. Uma contravenção maldosa e perigosa. Prejudicava a escritora em todos os sentidos. Livros proibidos sendo vendidos em bancas de jornal. O escritor, lesado, já não bastava a impossibilidade do controle de edições com determinados editores? (Rios, 1977: 112; grifo nosso).

Talvez essas gráficas clandestinas pensassem que infringir os direitos autorais de livros proibidos era um crime menor caso comparado à impressão e comercialização dos mesmos. Como a distribuição dos livros era tarefa das editoras, que nada sabiam e nem deveriam saber sobre essas impressões ilegais, as gráficas provavelmente recorriam aos atravessadores citados na reportagem do Jornal da República.

A reportagem também informava sobre o contrabando e comércio de pornografia internacional. Aos editores, livreiros e jornaleiros somavam-se outras personagens que, caso se considerasse o contexto de ilegalidade, não causavam surpresa: "Comprar revistas dinamarquesas, por exemplo, não é problema. Basta dar um toque num bicheiro. Apostas no bicho e compra de publicações pornográficas, ou filmes, correm na mesma faixa" (Passos, 1979). Como as bebidas proibidas pela Lei Seca americana, os livros censurados também fomentaram e mobilizaram o crime organizado.

Outro instrumento utilizado por esses circuitos paralelos era a venda de livros por reembolso postal. Gonçalo calcula que, entre os anos de 1950 a 1970, mais de 50 desses serviços funcionavam no país. Segundo ele, "o esquema se revelaria uma importante ferramenta para driblar a censura por causa dos livros de sexo. Sem a exposição em bancas e livrarias, evitavam-se queixas e pressões dos censores" (Gonçalo Junior, 2010: 104). Em sua edição de 24 de outubro de 1975, por exemplo, a revista Placar publicou um anúncio da Multilivros Editorial que vendia os seguintes romances por reembolso postal, além de livros de magia, educação sexual, judô e redação: $A$ vida secreta de um homem sensual, Love story e Os prazeres proibidos de Helen. Sobre este 
último, a sinopse era a seguinte: "A vida amorosa de uma mulher que estava sempre disposta a dar muito mais do que qualquer homem tem coragem de receber. Os prazeres de Helen seriam realmente proibidos?”. Ou os prazeres de Helen não eram proibidos ou a estratégia de reembolso postal funcionou neste caso, pois o livro passou despercebido pela censura. Por outro lado, segundo levantamento de Silva (1989), A vida secreta de um homem sensual não encontrou a mesma sorte, e o anúncio se aproveitou disto para vendê-lo como "única edição sem cortes da censura". Na verdade, a DCDP estava atenta ao comércio de livros pornográficos por reembolso postal, tanto que o diretor da divisão, em carta enviada a Ponto Promoções em 12 de maio de 1976, alertava a empresa de fazer "propaganda de livros, para entrega pelo reembolso postal, entre os quais figuram alguns proibidos de circular, como, por exemplo, O que excita as mulheres, Descubra o seu QI sexual, Fazendo amor, A hora do amor, Amor sem limite e Irene". Além de lembrar que o

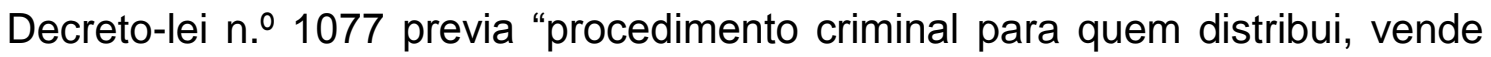
ou expõe livros e periódicos que tenham sido proibidos", o diretor esclarecia à empresa sobre a necessidade de "verificação prévia" de "livros que versem temas referentes a sexo, moralidade púbica e bons costumes" 8 .

Durante o desenvolvimento desta pesquisa, não se localizou nenhuma portaria proibindo a venda de livros pornográficos por reembolso postal. Contudo, algumas semanas antes do decreto-lei de 1970 perder a eficácia, a revista Placar (14 de dezembro de 1979) publicou um anúncio da Gom Time que parece indicar uma ordem informal de proibição: em letras grandes, o anúncio comemorava "Sensacional... Já liberada pela censura a venda pelo Reembolso Postal". Na verdade, caso se atente para os títulos anunciados, todos de Adelaide, inclusive alguns censurados (Mulher livre, Escuridão, Carniça, Orgia na TV, etc.), percebe-se que o anúncio comemorava principalmente a liberação dos romances da autora: segundo Gonçalo (2010, p. 370), ao final do ano de 1979, liberou-se as obras de Cassandra e Adelaide, bem como Zero de Brandão e algumas peças de Plínio Marcos.

Ao longo do regime de 64 , o papel da censura na relação entre obra e público aconteceu de duas maneiras principais: ou o público denunciava a

${ }^{8}$ Carta do diretor da DCDP, Rogério Nunes, à Ponto Promoções, 12 mai. 1976, Arquivo Nacional.

Revista Eletrônica Literatura e Autoritarismo: A opressão na ficcionalização da história - ISSN 1679-849X http://cascavel.ufsm.br/revistas/ojs-2.2.2/index.php/LA/index 
obra, pois a censura prévia de livros seria impossível sem a contribuição de censores amadores, devido ao montante de livros lançados comparado ao número de censores (Reimão, 2011: 30-31); ou o público era eliminado do sistema literário, visto que, a partir da censura, "estaria destruída a tríade indispensável que sustenta uma obra de arte, pois haveria autor e obra, mas não público" (Silva, 1989: 42; grifos do autor). Neste sentido, o crime cultural da censura é contra a sociedade, pois é o cidadão quem recebe paternalisticamente um "atestado de minoridade intelectual" (Santiago, 1982: 51). Inconformado com o seu atestado, o escritor Ricardo Ramos, entrevistado pelo jornal Folha de S. Paulo em 16 de julho de 1978, desabafou: "É humilhante não se poder assistir filmes ou peças, ler livros, revistas, ouvir músicas. É também humilhante só termos o que nos deixam ter, como se fossemos incapazes de saber o que nós queremos" (Marinho, 1978: 53). Havia ainda o papel ambíguo do mercado editorial que, apesar de personificar o inimigo da censura ao explorar o filão da literatura pornográfica, muitas vezes parasitava seu rival, pois, "ao contrário do que poderia esperar a censura, o livro proibido adquire um charme adicional com a proibição" (Silva, 1989: 32). $\mathrm{Na}$ verdade, mais que as obras censuradas, eram os escritores quem recebiam esse duvidoso "charme adicional", sendo explorado pelos editores em chamadas apelativas que estampavam as capas dos livros ("a escritora mais proibida do Brasil"). Portanto, o artista não lucrava com a censura, pois "há aí um óbvio sofisma, que alegra e ajuda, não há dúvida, mas só que ao comerciante que industrializa a arte: a gravadora, a distribuidora de filmes, a editora, o produtor, etc." (Santiago, 1982: 50).

Diante do crime cultural da censura e da exploração do mercado editorial, restava aos escritores populares se engajarem numa espécie de guerrilha literária. "Terroristas do sexo" fora a expressão que Cassandra utilizou para designar os homossexuais em seu romance Nicoleta Ninfeta (Rios, 1973: 85), mas que também serve para definir o projeto político-literário tanto dela quanto de sua colega Adelaide. A estratégia do terrorismo do sexo era multiplicar indícios do proibido, estabelecendo alianças perigosas que faziam do sexo uma bandeira política. Ver uma revista de sacanagem era tão perigoso quanto ler um livro marxista ou assistir uma peça de Chico Buarque. 
O terrorismo do sexo funcionava como todo terrorismo, se aproveitando dos noticiários para espalhar o terror: neste caso, denunciar a onda de moralismo que atravessava o país. Quando informados sobre mais um livro proibido das autoras, os seus muitos leitores reconheciam mais um cerceamento não apenas à liberdade de escrever, mas também de ler. Sentiam os prejuízos da onda de moralismo, principalmente quando rebaixava o nível intelectual da população brasileira. O terrorismo do sexo mostrava assim que "o jogo dos caçadores canibais" dava "bandeira demais", como cantou Raul Seixas em Metrô Linha 743 (1984). Na música de Raul, os "canibais de cabeça" diziam: "Eu avalio o preço me baseando no nível mental / Que você anda por aí usando / E aí eu the digo o preço que sua cabeça agora está custando". As cabeças de Cassandra e Adelaide custavam muito, pois o terrorismo do sexo empregava um "nível mental" que, apesar dos censores e dos intelectuais não o considerarem elevado, atingia vibrações populares. Eram cabeças que falavam a mesma língua de muitas outras cabeças brasileiras, sendo assim cabeças perigosas. 


\section{REFERÊNCIAS}

ALVES JUNIOR, Luiz. São Paulo, São Paulo, 1ํago. 2011. 1 fita cassete (90 minutos). Entrevista concedida a Rodolfo Rorato Londero.

AMÂNCIO, Moacir. Censura. Folha de S. Paulo, São Paulo, 20 jun., 1977. llustrada, p. 19.

ARQUIVO NACIONAL. Coordenação Regional do Arquivo Nacional no Distrito Federal. Fundo "Divisão de Censura de Diversões Públicas - DCDP".

CALDAS, Waldenyr. Subliteratura: o fetiche do prazer. Vozes, Petrópolis, v. 72, n. 3, p. 5-12, 1978.

CARTAS. Veja, São Paulo, n. 14, p. 3, dez. 1968.

CIVITA, Victor. Carta do editor. Veja, São Paulo, n. 12, p. 13, nov. 1968.

ESCARPIT, Robert. Sociologia da literatura. Trad. Anabela Monteiro; Carlos Alberto Nunes. Lisboa: Arcádia, 1969.

EXPLOSÃO erótica nas livrarias. Veja, São Paulo, n. 11, p. 60-63, nov. 1968.

FEIRANTES do livro desarmam barracas. Correio da Manhã, Rio de Janeiro, 31 mai., 1964. Primeiro Caderno, p. 9.

FICO, Carlos. "Prezada Censura": cartas ao regime militar. Topoi, Rio de Janeiro, v. 3, n. 5, p. 251-286, dez. 2002. Disponível em: <http://www.revistatopoi.org/ numeros_anteriores/topoi05/topoi5a11.pdf>. Acesso em: 20 abr. 2012.

FITTIPALDI, Mário. O livro, o escritor e a censura. In: MELO, José Marques de (org.). Censura e liberdade de imprensa. São Paulo: COM-ARTE, 1984.

GONÇALO JUNIOR. Maria Erótica e o clamor do sexo: imprensa, pornografia, comunismo e censura na ditadura militar. São Paulo: Editoractiva, 2010.

. Malditas escritoras. Jornal da ABI, n. 378, p. 30-32, mai. 2012.

LIVROS apreendidos pelo Juizado. Diário Carioca, Rio de Janeiro, 23 mai., 1964. s. p.

MARCELINO, Douglas Attila. Salvando a pátria da pornografia e da subversão: a censura de livros e diversões públicas nos anos 1970. Rio de Janeiro: UFRJ, 2006. 300 p. Dissertação (Mestrado) - Programa de Pós-Graduação em História Social, Universidade Federal do Rio de Janeiro, Rio de Janeiro, 2006.

MARINHO, Celso. Literatura censurada: os autores pensam em união. Folha de S. Paulo, São Paulo, 16 jul., 1978. Ilustrada, p. 53. 
MARKUN, Paulo Sérgio. Em todas as bancas, a explosão do sexo. Jornal da República, São Paulo, 20 nov., 1979. s. p.

PAIVA, Salvyano Cavalcanti de. O desarmamento (ou Novo Memento) moral da universitária. Correio da Manhã, Rio de Janeiro, 8 nov., 1968. Primeiro Caderno, p. 2.

PASSOS, José Meirelles. O longo e caro caminho das proibidas. Jornal da República, São Paulo, 20 nov., 1979. s. p.

REIMÃO, Sandra. Repressão e resistência: censura a livros na ditadura militar. São Paulo: Edusp, 2011.

RIOS, Cassandra. Nicoleta ninfeta. Rio de Janeiro: Record, 1973.

. Censura. São Paulo: Global, 1977.

ROLLEMBERG, Denise; QUADRAT, Samantha Viz. Apresentação. In: ROLLEMBERG, Denise; QUADRAT, Samantha Viz (orgs.). A construção social dos regimes autoritários: Brasil e América Latina. Rio de Janeiro: Civilização Brasileira, 2010.

SANTIAGO, Silviano. Vale quanto pesa: ensaios sobre questões políticoculturais. Rio de Janeiro: Paz e Terra, 1982.

SÃO PAULO apreende os livros imorais. Última Hora, Rio de Janeiro, 4 abr., 1962. Primeiro Caderno, p. 4.

SETE dias do Presidente. Veja, São Paulo, n. 73, p. 18-20, jan. 1970.

SEXO lidera vendas na Feira do Livro. Diário de Notícias, Rio de Janeiro, 8 jun., 1975. s. p.

SILVA, Deonísio da. Nos bastidores da censura: sexualidade, literatura e repressão pós-64. São Paulo: Estação Liberdade, 1989. 